\title{
Knowledge Innovation in E-business enterprises
}

\author{
Shaohua He ${ }^{1}$ Peilin Wang ${ }^{2}$ \\ 1 Electronic Commerce Market Application Technology, \\ Guangdong University of Business Studies, China, \\ hshua@email.whu.edu.cn \\ 2 School of Information Management, Wuhan University, \\ China, \\ wsai_ll@163.com
}

\begin{abstract}
E-business is not a new topic, and many authors made many researches on this topic, such as the relationship between e-business and competitiveness, the advantages of e-business, e-business and knowledge management, e-business and management innovation, and so on. However, knowledge innovation in e-business enterprises is an ignored field. In fact, different kinds of companies at present considered knowledge innovation as the key factor for getting sustainable competitive advantage, no exception of ebusiness enterprises. Therefore, this paper chose knowledge innovation in ebusiness as its topic, and analyzed the relationship between e-business and knowledge innovation, and then explored the impact of knowledge innovation on e-business. In the end, it tried to analyze the knowledge innovation in ebusiness, including product and service innovation, technology innovation, and management innovation. These elements were then further decomposed.
\end{abstract}

\section{Introduction}

In general, e-business is the business activities on internet. When the business in a company is directly connected with the staff, customers, suppliers, and partners by intranet, extranet, and internet, various activities in those processes are e-business [1]. In the process of transforming from traditional business to electronic business, business environment is changing, the competition confronted by the company at home and abroad is increasing, and the product innovation is speeding up. Thus, in order to get the rapid response for the changing market, business crisis, and the transition to knowledge-based products/service, it is important for the companies to

Please use the following format when ciling this chapter.

He, S., Wang, P., 2007, in IFIP International Federation for Information Processing, Volume 251, Integration and Imnovation Orient to E-Society Volumel, Wang, W. (Lds), (Boston: Springer), pp. 459-466. 
realize knowledge innovation. It is essential for the company to integrate the reserved information resources with staffs' experience by knowledge innovating to sustain its competitive advantage, so that the company can effectively explore, share, and utilize knowledge, which lead the company to understand the special knowledge it captures and know how to utilize these knowledge to develop.

As a summary, the evidence proves that e-business enterprises must depend on knowledge innovation to get the competitive advantage, and transits from businesscentered and company-centered model to the customers-centered and knowledgecentered business model. Therefore, the purposes of this study are as follows.

(1) An exploration of the interrelationship between e-business and knowledge innovation.

(2) An exploration of the knowledge innovation in e-business, including product /service innovation, technology innovation, and management innovation. These elements were then further decomposed.

\section{The Core of E-business Enterprises is Knowledge and Innovation}

The appearance of internet and e-business changes the characteristics of the market, and leads to the appearance of new critical success factors, which change the competitive rules and influence the competitive environment. In the new business model, the competitive environment becomes boundless. As internet provides a greater marketing space for tradesmen, the limitations of space and time are more and more little. And the virtual world provided by internet leads to the products spontaneously spread all over the world. However, e-business brings uncertainty to the competitive environment at the same time. Technological change, global communication and the development of internet all reveal that the present environment is more complex and more uncertain than ever. As information technology integrating and the internet developing, the company cannot only rely on overall cost leadership, differentiation and focus provided by Michael E. Porter to competitive advantage. Knowledge becomes a new source of competitive advantage, and no exception of e-business. E-business enterprises therefore have to depend on not only cost leadership, differentiation and focus, but also on knowledge and innovation to reduce the uncertainty [2].

On the other hand, the main characteristics of e-business enterprises decide that e-business enterprises have to depend on knowledge and innovation to some extend. E-business is a new business model based on computers and internet technology, which pays more attention to knowledge and innovation than traditional business (see Table 1 [3]). And as the development of technology and the rapid reduction of the cost, there is little barrier for entering the e-business model, so that the competitors can catch up with or even exceed the company by lower cost and more advanced technology. If the company is the follower of e-business, it will lose its competitive advantage. Therefore, e-business enterprises really depend on not their rich capital but abundant knowledge resources, whose main resources of operation and risk are knowledge capital and customer relationship capital. And among those 
capitals in one company, knowledge capital is the leading capital, which decides the increase of customer relationship capital. Therefore, the value of the company is not its workshops, equipment or products, but its intellectual property, the degree of reliance of customers, the cooperation with partners, information infrastructure, and the innovative capacity and expertise of the staffs. In other words, the fundamental advantage of e-business enterprises is their advanced knowledge, which depends on knowledge innovation. And knowledge capture, process, integration, innovation are the strong pushes of e-business enterprises, and knowledge has become the critical factor for the development of e-business enterprises. And we can infer accordingly that the core of e-business enterprises is knowledge and innovation, and the following part will discuss the impacts of knowledge innovation on e-business.

Table 8. The Comparison of Traditional Business and E-business

\begin{tabular}{|c|c|c|}
\hline & Traditional business & e-business \\
\hline Assets & tangible assets & Intangible assets \\
\hline Strategy & expecting & $\begin{array}{c}\text { Improving the capacity of meet } \\
\text { an emergency }\end{array}$ \\
\hline Information technology & centralized & decentralized \\
\hline Role of senior managers & obedience & Self-control \\
\hline $\begin{array}{c}\text { The process of } \\
\text { management }\end{array}$ & application & innovation \\
\hline
\end{tabular}

\section{Impacts of Knowledge Innovation on E-business Enterprises}

The above part has inferred that the core of e-business enterprises is knowledge and innovation, and this part will discuss the impacts of knowledge innovation on ebusiness to prove that knowledge innovation is the key factor of e-business.

Firstly, knowledge innovation helps e-business enterprises create new ideas to start new business [4]. Considering e-business as a new business model, many pioneers have entered into this field and started different kinds of business, such as electronic retail company (for example, Amazon bookstore), electronic auction company (for example, eBAY), electronic direct distribution (for example, DELL), electronic street (for example, euyar). All of these businesses create great economical and social benefit. But these businesses are created not by accident, but by the capacity of observing the market and the sense of innovation by the pioneers. They have captured the soul of knowledge innovation-creating knowledge. As the research on knowledge innovation and e-business deepens, there are more and more people to unconsciously utilize knowledge innovation theory to start e-business.

Secondly, knowledge innovation is good for e-business to accumulate and transfer information and knowledge [5], develop new products and improve business [6], and enhance the capacity of response [7], which are critical to the development of e-business. As knowledge innovation is a cooperative innovation, use of computer 
and internet technology lead e-business to access to customers and suppliers. Knowledge alliance between e-business and other companies (such as distribution enterprises and banks) benefits e-business for reducing the time and cost of the research, and improving the capacity of innovation as well. For example, General automobile builds knowledge alliance with Toyota to develop manufacturing technology of automobiles, and IBM builds partnership with France telephone Co. to develop communication technology. E-business expands the customer groups, and brings large amount of out-of-order information as well. Therefore, the company has to process, organize, transfer the information, and change it into knowledge in time to improve the efficiency, which demand the use of database or knowledgebase and the tools of knowledge innovation. Through knowledgebase, e-business can directly communicate with various customers, and provide the customers with special service to meet their needs.

Thirdly, knowledge innovation builds new competitive rules for e-business enterprises [8]. In the competition of e-business, the company should not stress on how to compete in fixed rules, but pay more attention to understand and adapt the changing competitive rules. The dynamic change of environment leads to that the best practice of yesterday becomes the barriers of tomorrow, which demands the company adjust according to the change of the business and information infrastructure and learn how to utilize old knowledge and new knowledge. In one word, e-business enterprises have to develop knowledge-innovation-centered competitiveness to adapt the dynamic market in order to survive in the competition.

Fourthly, knowledge innovation helps e-business build or sustain competitive advantage. Business activities in e-business are knowledge in themselves, which are convenient to capture the internal knowledge, external knowledge, fact knowledge and workers' ideas. And the process of analyzing the information in database is in essence knowledge innovation. Therefore, the company should create the knowledge in e-business and learn from business activities. And the capacity of innovation decides the amount of value-added knowledge in business. That is to say, because different companies have different capacity of innovation, they will get different experience from similar business activities, which is mainly methodological knowledge and included in the core capacity of the company to get competitive advantage in similar business activities. For example, Dupont had deal with Dye industry, learned from it and had some creation in the field of Synthetic fiber. And finally it got the necessary knowledge on dye synthesis and its utilization, which make the company believe that they are able to solve the problem of dye coloration. Thus, the company started to develop nylon and succeeded.

In a summary, e-business and knowledge innovation are interrelated, and knowledge innovation is the key factor of e-business. E-business companies have to get knowledge innovation to get the competitive advantage, and the following part will further explore how e-business companies realize knowledge innovation. 


\section{Knowledge Innovation in E-business Enterprises}

Although there is not a fixed definition of knowledge innovation, most authors accepts that knowledge innovation is the whole process from knowledge creation to knowledge utilization. Enterprises' knowledge innovation means applying created knowledge into the production, including products development and improvement, process innovation, service innovation, organization innovation, strategy innovation, and technology innovation as well. In e-business enterprises, knowledge innovation mainly includes products and service innovation, management innovation, and technology innovation. And this part will explore knowledge innovation in ebusiness by analyzing those three kinds of innovation.

\subsection{Products/Service Innovation}

According to Osterwalder etc. , products/service innovation is one of the important components in e-business [11] (see Figure 1). And the elements of products/service innovation cover all aspects related to the offering of the firm. Those comprise not only its products/service but the manner in which the company differentiates itself from its competitors. In other words, this includes not only the firms market scope [9] [10] - customers, geographical areas, and product segments - but also the explanations why customers will buy from this firm rather than from a competitor. Moreover, the ability to offer value for a customer demands a range of specific capabilities.

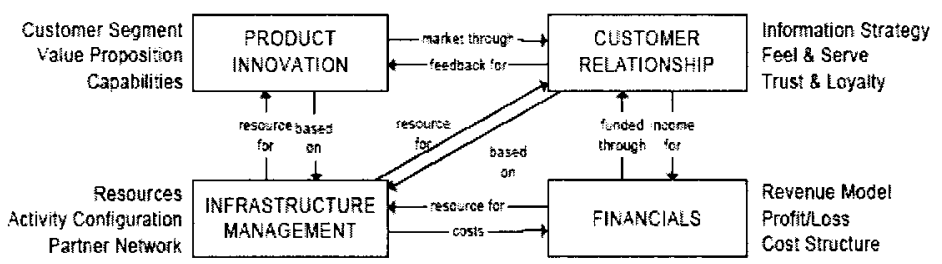

Fig. 1. The 4 Pillars Of the Business Model Ontology by Osterwalder etc. (Resources: Osterwalder, A. Pigneur, Y. An E-business Model Ontology for Modeling Ebusiness. In the Proceedings of the 15th Bled Electronic Commerce Conference Bled, Slovenia, June 17-19, 75-91(2002))

As the cost for entrance to e-business is low, every person or company can easily enter into e-business, and similar companies in e-business provide similar products or service, which result in the fierce competition in e-business. Thus, under the condition of technology and the requirement of customers changing, e-business enterprises have to stress products/service innovation to survive and sustain. Ebusiness enterprises are able to realize products/service innovation in two ways. One is to create new products/service, and the other is to explore new property of existed products/service. In order to realize products/service innovation, e-business enterprises have to get the interrelated knowledge on new products or service and existed products or service firstly, including whether there are similar products or 
service in the market or not, which are interrelated products or service, whether the company developed similar products or service, the new requirement of customers for the products and their expectations, and the cost and profit of developing the new products or service. Then, the company can create knowledge by focusing on the market and making regular research, and by participating into the projects or imitating other companies as well. The process of innovation is the process from intuitive tacit knowledge to more exact knowledge like figures, and to literature knowledge such as document or digital knowledge, and finally to utilize literature knowledge to create explicit knowledge.

\subsection{Technology Innovation}

Technology innovation is also one of important components of e-business. One of the premises of the development of e-business is information infrastructure, which includes internet. One of the important reasons for the development of e-business in America is that information infrastructure including internet in America builds a broad platform for e-business. Therefore, e-business enterprises have to stress technology innovation. The capacity of technology innovation is the integrative capacity by which the company creates new ideas and puts into practice. From the point of knowledge, the capacity of technology innovation is the capacity which inspires external knowledge of the company and integrates and creates knowledge to realize its value [12]. And from the point of innovation, the capacity of technology innovation is knowledge creation and inspiration in nature. And knowledge creation and inspiration depend on the improvement of innovation system and reward system. Otherwise, the inspiration of the knowledge in knowledgebase depends on its developing environment. Thus, the company has to improve its environment to get, create and inspire new knowledge for technology innovation.

\subsection{Management Innovation}

Management innovation is to make use of new management thoughts to promote the management innovation of e-business and build an appropriate advanced management model [13]. Management innovation should be harmony with technology innovation and new business theory. When the company starts e-business, it is difficult to carry out the traditional management theory which pays attention to division and accuracy. The company should innovate and integrate according to new requirements for safe, accurate and efficient management. The company can not ignore the coherence between management innovation and technology innovation. For example, in customized internet marketing, the company must depend on software to manage effectively. At the same time, the company depends on its products to design the best customers-oriented business solution which is based on information feedback, interactive communication and track service to realize customers' benefit and the company's revenue. 


\section{Conclusion}

There are several reasons why academic research should be done in the area of knowledge innovation in e-business enterprise. First of all, even though many people talk about e-business, rare are knowledge innovation which is the key for the development of e-business. Executives, reporters and analysts who use the term do not have a clear idea of how to realize e-business.

The second reason why knowledge innovation in e-business enterprises is interesting to be studied is that it can be a foundation for e-business enterprises and an application of knowledge innovation theory. As product life cycles become shorter, competition global and the use of information technology are imperative, managers have to find new ways to decide in this complex environment. Managers have to understand the new opportunities offered by information technology, integrate them into their existing business models and share them with other stakeholders. The knowledge innovation in e-business enterprises we propose in this paper is a first step to facilitating management under uncertainty.

\section{References}

1. Kequn, Ch. Enterprise Management and Its Creation in the Environment of Electronic Commerce. Journal of Anhui Agricultural University(social science edition). 1(4), 52-54 (2002)

2. Wenwu, Z. Peilin, W. Information Risk in E-business and Its Countermeasure. Group Economy. 3, (2007)

3. Juan, Zh. etc. Analyzing the Development of Enterprises from the Relationship Between Ebusiness and Knowledge Management. China Rural Enterprise Techniques Market. 5, 40$41(2005)$

4,5,8. Wei,Ch. Delu, W. Shaoxia,Q. Knowledge Management and E-business. Future and Development.6, 7-8(2001)

6,7. Yang, Y. Discussion on Electronic Commerce Enterprise and Knowledge management. Pioeering With Science \& Technology Monthly. 4, 95-96 (2006)

9. Hamel, G., Leading the Revolution, Boston: Harvard Business School Press. 35-36(2000)

10. Afuah, A., C. Tucci . Internet Business Models and Strategies, Boston: McGraw Hill. 56$71(2001)$

11. Osterwalder, A. Pigneur, Y. An E-business Model Ontology for Modeling E-business. In the Proceedings of the 15th Bled Electronic Commerce Conference Bled, Slovenia, June 17-19, 75-91(2002)

12. Yi, Ouy.. Haichun, G. Knowledge Management Strategy in E-business Enterprises. World Standardization and Quality Management. 8, 37-39 (2005)

13. Yuean, $X$. Innovation on the Development of E-business and Its Environment. Commercial Times. 8, 26-28 (2001)

14. Hong, Zh. etc. A System Structure of Knowledge Management based on E-commerce at Baosteel Yichang Company. Industrial Engineering and Management. 2, 125-130 (2005)

15. John Flower. Internet Economic: The Coming of Digital Business Era. Worldwide Concert Corp. 206-228(1997) 
16. M.A. Saren. A Classification and Review of Models of the Intra-firm Innovation Process. R\&D Management. 14(1), 11-24 (1984)

17. Adamantia G. Pateli, George M. Giaglis, A Framework for Understanding and An Analyzing eBusiness Models. 16th Bled E-commerce Conference E-Transformation Bled, Slovenia, June 9-11 (2003) 